COUNSENESIA
Indonesian Journal of Guidance and Counseling
www.ejournal.utp.ac.id /index.php/CIJGC

\title{
PENGEMBANGAN KARTU TENTANG PEKERJAAN (KTP) SEBAGAI MEDIA BIMBINGAN KARIER ANAK USIA 7-10 TAHUN
}

\author{
Fia Nurul Fauziah', Reggy Fernanda ${ }^{2}$, Dini Rizqi Lestari ${ }^{3}$ \\ 1,2,3 Universitas Negeri Jakarta, Jakarta \\ Email: fianuru105@gmail.com
}

\begin{abstract}
Info Artikel
Abstrak

Riwayat Artikel

Diterima:

4 Maret 2021

Disetujui:

18 April 2021

Publikasi:

Juni 2021

DOI :

Penelitian ini bertujuan untuk mengembangkan Kartu Tentang Pekerjaan (KTP) di RPTRA Beringin Indah Jakarta Timur sebagai media kreatif dalam layanan bimbingan karier di masyarakat. Populasi penelitian ini adalah seluruh anak usia 7-10 tahun di RPTRA Beringin Indah Jakarta Timur dengan sampel penelitian sebanyak 15 anak. Metode yang digunakan adalah research and development. Pengambilan sampel dengan teknik convenience. Pengumpulan data dilakukan dengan wawancara dan angket. Hasil Penelitian ini adalah media kartu mengenai pekerjaan yang diberinama Kartu Tentang Pekerjaan (KTP) yang berjumlah 15 Kartu Tanya, 15 Kartu Info, 1 Papan Permainan, 1 Panduan Permainan dan 1 Video Tutorial Cara Bermain. Kartu Tentang Pekerjaan (KTP) ini telah dinilai oleh dua ahli materi mendapatkan nilai sebesar $80 \%$ dan ahli media mendapatkan nilai 86,6\%. Maka Kartu Tentang Pekerjaan (KTP) ini dinyatakan layak untuk dilakukan uji coba terbatas dan uji coba luas.
\end{abstract}

Kata Kunci: Media, bimbingan Karier, Penelitian dan Pengembangan.

\begin{abstract}
This study aims to develop a Card about Employment (KTP) in Beringin Indah East Jakarta RPTRA as a creative media in career guidance in the community. The population of this research is all children aged 7-10 years in RPTRA Beringin Indah East Jakarta with a sample of 15 children. The method used is research and development. Sampling with convenience technique. Data collection was carried out by interview and questionnaire. The results of this study are the media of employment cards named Cards about Employment (KTP) totaling 15 Question Cards, 15 Info Cards, 1 Board Game, 1 Game Guide and 1 Video Tutorial How to Play with the cards. The Card about Employment (KTP) has been assessed by two material experts as having a value of $80 \%$ and a media expert getting a value of $86.6 \%$. Then this Card About Employment (KTP) is declared eligible for limited trials and extensive trials.
\end{abstract}

Keywords: Media, Career Guidance, Research and Development.

(C) 2021 Universitas Tunas Pembangun Surakarta

ISSN: 2746-3532 (Online) 


\section{PENDAHULUAN}

Perkembangan ilmu pengetahuan, teknologi, dan informasi yang semakin berkembang dengan pesat memiliki dampak pada setiap aspek perkembangan manusia. Disisi lain Indonesia membutuhkan sumber daya manusia yang memiliki kemampuan tinggi dalam menghadapi kecakapan di era globalisasi. Untuk mengantisipasi hal tersebut dapat dilakukan dengan cara mempersiapkan sumber daya manusia yang unggul dimulai dari usia sedini mungkin. Sebab, anak-anak merupakan generasi penerus yang memiliki peran penting dalam eksistensi bangsa di masa depan. Upaya layanan bimbingan karir perlu diberikan kepada anak sekolah dasarbahkan dimulai sebelum taman kanak-kanak dengan asumsi bahwa perkembangan karir mempertimbangkan proses sepanjang hayat, program karir komprehensif disesuaikan usia dan pengalaman (Zunker dalam Hanani, 2016). Upaya pengenalan karir sejak usia anak - anak menjadi penting di era globalisasi, hal tersebut dapat membantu anak - anak dalam memilih dan melanjutkan studi ke jenjang yang lebih tinggi.

Masa anak-anak akhir merupakan fase kehidupan yang sangat penting dalam siklus perkembangan individu, karena pada masa ini seorang individu dapat menentukan arah masa depan mereka baik di fase remaja maupun dewasa. Masa ini menunjukan dengan jelas perkembangan kreativitas, bakat dan minat yang anak. Untuk memanfaatkan ataupun mengasah bakat dan minat yang dimiliki oleh anak-anak tersebut dibutuhkan sebuah pengembangan karier sejak usia anak-anak akhir sehingga tujuan masa depannya bisa terarah dan terstruktur. Pemberian bimbingan karier sebaiknya mulai diperkenalkan pada kanak-kanak bukan saja hanya diperkenalkan pada masa remaja akhir ataupun masa dewasa. Kegiatan bimbingan karier dimulai sejak anak berada di sekolah dasar dengan penekanan pada pengembangan kesadaran karier, sementara di sekolah menengah aktivitas bimbingan karier lebih diarahkan pada pengembang kesadaran Karier, eksplorasi dan perencanaan karier (Gysbers, 2005).

Layanan bimbingan karier yang diberikan oleh guru sekolah dasar kepada siswanya memilki pedoman pada Peraturan Menteri Pendidikan dan Kebudayaan Republik Indonesia Nomor 111 tahun 2014 Tentang Layanan Bimbingan Karier terdiri atas pengembangan sikap positif terhadap pekerjaan, pengembangan keterampilan menempuh masa transisi secara positif dari masa bersekolah ke masa bekerja, pengembangan kesadaran terhadap berbagai pilihan karier, informasi pekerjaan, ketentuan sekolah dan pelatihan kerja, kesadaran akan hubungan beragam tujuan hidup dengan nilai, bakat, minat, kecakapan, dan kepribadian masing-masing.

Jika hanya ditekankan pada sekolah formal saja, banyak anak-anak di usia tersebut terutama yang berkegiatan di lembaga non formal akan terabaikan karena tidak tersentuh dengan program perkembangan karier tersebut. Sementara banyak anak-anak di kota jakarta sendiri yang menghabiskan waktu sepulang sekolah di tempat-tempat bermain, tempat kursus atau bahkan RPTRA. Ruang Publik Terpadu Ramah Anak adalah ruang publik yang memiliki karakteristik sebagai taman terbuka publik, wahana permainan dan tumbuh kembang anak, bagian dari prasarana dan sarana kota layak anak, ruang terbuka hijau, dan sarana kegiatan sosial yang dilengkapi dengan berbagai permainan menarik, pengawasan CCTV, ruang perpustakaan, PKK Mart, ruang laktasi, dan lainnya Herwanto dalam (Herlina \& Nadiroh, 2017).

Penggunaan media pembelajaran penting dalam pelaksanaan pembelajaran baik di sekolah maupun di luar sekolah sebagai salah satu alat penunjang pembelajaran dan pengajaran yang dilakukan oleh guru. Seiring berkembangnya zaman dan teknologi media yang digunakan berkembang dan seorang guru seharusnya mampu untuk berinovasi dan 
mengembangkan media pembelajaran yang akan digunakan dalam pembelajaran. Pengembangan media adalah suatu inovasi yang dilakukan untuk membuat media yang lebih baik, menarik dan efektif untuk digunakan dalam pembelajaran.

Media bimbingan dan konseling adalah usaha kreatif dan inovatif guru bimbingan dan konseling atau konselor untuk menghasilkan produk yang mampu menjembatani penyampaian pesan bimbingan dan konseling yang dapat merangsang pikiran, perasaan, perhatian, dan kemauan peserta didik/konseli untuk menangkap pesan dengan tepat. Media bimbingan dan konseling tersebut dalam bentuk cetak atau elektronik/digital. Pengembangan media bimbingan dan konseling berupa leaflet, poster, booklet, banner, web blog, video interaktif, photo voice, dan lain-lain memperhatikan dukungan sarana/fasilitas, setting/layout, daya tarik, konten media, penempatan, keterbacaan, komposisi, daya tarik. (Kemendikbud, 2016)

Pembuatan media pembelajaran bukanlah hal yang sepele, harus ada beberapa hal penting yang diperhatikan misalnya saja katan media dengan aspek perkembangan anak. Berikut adalah syarat-syarat media pembelajaran yang baik bagi anak : 1) Aman dan tidak membahayakan bagi anak-anak; 2) Sesuai dengan tujuan dan fungsi mengembangkan potensi anak; 3) Memenuhi unsur kerapihan dan keindahan; 4) Menarik, menyenangkan dan tidak membosankan bagi anak; 5) Dapat digunakan secara individual, berkelompok ataupun secara klasikal; 6) Memicu aktivitas dan kreativitas anak; dan 7) Kuat dan dapat dimanfaatkan dalam waktu yang cukup lama (Kustiawan, 2016).

Media pembelajaran adalah alat komunikasi yang digunakan dalam proses pembelajaran untuk membawa informasi berupa materi ajar dari guru kepada murid sehigga murid menjadi lebih tertarik untuk mengikuti kegiatan pembelajaran (Kustiawan, 2016). Pengembangan media pembelajaran Kartu Tentang Pekerjaan (KTP) menggunakan teori yang dikembangkan oleh Eli Ginzberg karena teori tersebut berkaitan dengan perkembangan manusia dalam pemilihan karier, khususnya yang akan dikembangkan adalah media untuk anak dalam masa perkembangan karier pada anak-anak.

Teori dasar yang dikembangkan oleh Ginzberg (1971) ada tiga yaitu : 1) Pemilihan pekerjaan adalah sebuah proses; 2) Prosesnya luas dan tidak dapat diubah; 3) Kompromi adalah aspek penting dalam setiap pilihan. Proses yang dimaksud dialami sepanjang hidup manusia yaitu dari lahir hingga meninggal dunia. Eli Ginzberg membuat analisis mengenai proses pemilihan pekerjaan dalam tiga periode yaitu: 1) Fantasi (usia sebelum 11 tahun). Pada tahap ini anak dalam periode fantasi mempercayai bahwa ia dapat menjadi apapun yang dia inginkan, anak membuat kesewenang-wenangan dalam mengartikan dorongan dan kebutuhan pada pemilihan pekerjaannya; 2) Tentatif (usia antara 11-17 tahun). Pada periode tentatif biasanya menerjemahkan secara subjektif pada beberapa faktor misalnya daya tarik, kapasitas dan nilai. Remaja menganggap bahwa keputusan yang dipilih masih bisa berganti-ganti karena mereka tidak secara langsung menggabungkan realitas dalam pertimbangan mereka; 3) Realistik (usia antara 17 tahun dan dewasa muda ketika seseorang membatasi pilihannya). Periode realistik manusia berusaha untuk bekerja dengan kompromi antara kepentingan, kapasitas, nilai-nilai, peluang, keterbatasan dan lingkungan. Menurut Barubara (2013) hal dasar dalam teori Ginzberg dikelompokkan dalam empat unsur yaitu: 1) pekerjaan yaitu proses yang berlangsung terus menerus; 2) pekerjaan tidak bisa diubah atau dibalik secara cepat karena ada batasan tertentu; 3) pekerjaan merupakan kompromi antara antara minat, kemampuan, dan nilai; 4) individu yang mencari kecocokan kerja, baik antara minat yang terus mengalami perubahan, tujuannya, dan keadaan yang terus berubah. 
Menurut Wetik dalam Afandi (2011) memaparkan pengertian bimbingan karier adalah program pendidikan berupa layanan terhadap siswa agar dapat mengenal dirinya sendiri, mengenal dunia kerja, dapat memutuskan apa yang diharapkan dari pekerjaan dan dapat memutuskan bagaimana bentuk kehidupan yang diharapkannya disamping pekerjaan untuk mencari nafkah. Tujuan bimbingan karier di sekolah tentunya berpatokan dengan target pengembangan diri peserta didik, menurut Gani dalam Afandi (2011) tujuan bimbingan karier yaitu : 1) Dapat menilai dan memehami dirinya terutama mengenai potensi-potensi dasar, minat, sikap dan kecakapan; 2) Mempelajari dan mengetahui tingkat kepuasan yang mungkin dapat dicapai dari suatu pekerjaan; 3) Mempelajari dan mengetahui berbagai jenis pekerjaan yang berhubungan dengan potensi dan minatnya; 4) Memiliki sikap positif dan sehat terhadap dunia kerja, artinya siswa dapat memberikan penghargaan yang wajar terhadap setiap jenis pekerjaan; 5) Memperoleh pengarahan mengenai semua jenis pekerjaan yang ada di lingkungannya; 6) Mempelajari dan mengetahui jenis-jenis pekerjaan atau latihan yang diperlukan untuk suatu pekerjaan tertentu; 7) Dapat memberikan penilaian pekerjaan secara tepat; 7) Sadar dan akan memahami nilai-nilai yang ada dirinya dan pada masyarakat; 8) Dapat menemukan hambatan-hambaan yang ada pada diri dan lingkungannya dan dapat mengatasi hambatanhambatan tersebut; 9) Akan sadar tentang kebutuhan masyarakat dan negaranya yang berkembang; 10) Dapat merencanakan masa depannya sehingga dia dapat menemukan karier dan kehidupannya yang serasi dan sesuai.

\section{METODE}

Metode penelitian yang digunakan dalam penelitian ini adalah Research and Development $(R n D)$. Penelitian dan pengembangan atau Research and Development $(R n D)$ adalah sebuah strategi atau metode penelitian yang cukup ampuh memperbaiki praktik. Penelitian dan pengembangan merupakan suatu proses atau langkah-langkah untuk mengembangkan suatu produk baru atau menyempurnakan produk yang telah ada dan dapat dipertanggungjawabkan. Pada penelitian pengembangan ini mengacu pada prosedur penelitian pengembangan menurut Sugiyono (2009) terdapat 5 langkah yang disesuaikan dengan kebutuhan peneliti, yaitu: 1) potensi dan masalah; 2) pengumpulan data; 3) desain produk; 4) validasi desain; 5) revisi desain produk. Langkah-langkah prosedur pengembangan tersebut dapat digambarkan sebagai berikut:

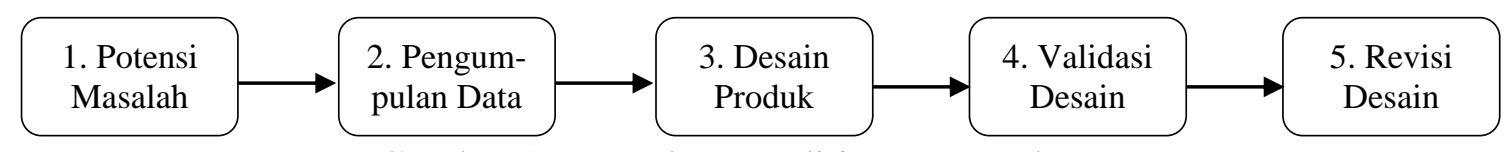

Gambar 1. Prosedur Penelitian Pengembangan

Penelitian dilaksanakan di RPTRA Beringin Indah Jakarta Timur dengan waktu selama empat bulan yaitu pada bulan Juni 2019 hingga Sepember 2019. Subjek penelitian pada penelitian pengembangan ini terdiri dari ahli media, ahli materi, dan 12-15 orang anak usia 7-10 tahun di RPTRA beringin indah. Teknik pengumpulan data yang digunakan dalam penelitian ini yaitu dengan observasi, studi pustaka, dan angket. Observasi dilakukan ketika diawal penelitian untuk memperoleh data sebagai dasar dilaksanakan penelitian dan pengembangan. Wawancara dilakukan kepada anak-anak di RPTRA untuk mengetahui pengetahuan anak-anak tentang nama-nama perkerjaan. Selain observasi dan wawancara, peneliti juga melakukan studi pustaka terkait bimbingan karier pada usia anak 7-10 tahun melalui buku, jurnal, dan sumber lainnya. Angket digunakan utuk memperoleh 
data penelitan kualitas kelayakan media yang dikembangkan menurut ahli media, ahli materi dan anak-anak pada ujicoba lapangan skala kecil.

\section{HASIL DAN PEMBAHASAN}

Penelitian ini memiliki tujuan untuk mengembangkan media Kartu Tentang Pekerjaan (KTP) sebagai media bimbingan Karier anak usia 7 sampai 10 tahun di RPTRA Beringin Indah Jakarta Timur. Kartu Tentang Pekerjaan adalah sebuah media yang dikembangan untuk menunjang penyampaian informasi mengenai macam-macam pekerjaan dengan lebih menarik dan inovatif. Kartu Tentang Pekerjaan meliputi : 1) Kartu Info Pekerjaan; 2) Kartu Tebak Pekerjaan; 3) Papan Permainan; 4) Petunjuk Penggunaan; 5) Video Cara Bermain. Pengembangan media ini melalui lima tahapan yang dilakukan oleh peneliti, yaitu tahap mencari potensi dan masalah, tahap pengumpulan data, tahap desain, tahap validasi, revisi desai atau tahap analisis, desain dan pengembangan. Hal ini dilakukan karena terbatasnya waktu yang diberikan. Berdasarkan data yang diperoleh selama melakukan penelitian, maka langkah-langkahnya yaitu:

1. Potensi dan Masalah

Berdasarkan hasil pengamatan dan wawancara anak usia 7 sampai 10 tahun di RPTRA Beringin Indah, peneliti menemukan fakta bahwa hampir semua anak di lingkungan tersebut bercita-cita menjadi seorang dokter, hanya ada satu dari enam anak yang ditanya yang memiliki jawaban yang berbeda yaitu menjadi koki. Hal tersebut mengindikasikan bahwa banyak anak yang belum memiliki gambaran mengenai pekerjaan-pekerjaan yang ada di lingkungan mereka sehingga mereka cenderung menyebutkan pekerjaan yang sama. Maka peneliti menyimpulkan perlu adanya bimbingan karier dalam pendidikan informal misalnya di RPTRA Beringin Indah. Menurut Winkel dalam Lestari (2017) bimbingan karier adalah bimbingan dalam mempersiapkan diri menghadapi dunia pekerjaan, dalam memilih lapangan pekerjaan atau jabatan/profesi tertentu serta membekali diri supaya siap memangku jabatan itu, dan dalam menyesuaikan diri dengan berbagai tuntutan dari lapangan perkerjaan yang telah dimasuki. Menurut kakak pengajar dan pengelola RPTRA Beringin Indah Jakarta Timur bahwa anak-anak antusias dengan pembelajaran menyenangkan menggunakan media pembelajaran yang unik dan menarik salahsatunya menggunakan flashcard atau kartu. Oleh karena itu, peneliti mengembangkan media pembelajaran berupa Kartu Tentang Pekerjaan (KTP) yang dapat mendukung proses pemberian informasi mengenai karier dan macam-macam pekerjaan.

2. Pengumpulan data

Pada tahap ini peneliti mengumpulkan data melalui hasil wawancara dan pengamatan, studi pustaka mengenai media yang baik dan cocok untuk anak-anak serta mengumpulkan nama-nama pekerjaan yang akan diperkenalkan kepada anak-anak. Berdasarkan hasil wawancara ditemukan fakta bahwa sebagian besar anak di RPTRA Beringin Indah masih belum memiliki pengetahuan mengenai ragam pekerjaan. Peneliti menemukan beberapa penelitian pengembangan media yang telah dikembangkan, yaitu penelitian yang dikembangkan oleh Wardati dan Wangid (2015) 
dengan sampel siswa SD kelas I dalam jurnal yang berjudul "Pengembangan Media Permainan Kartu Gambar dengan Teknik Make A Match untuk Kelas I SD”. Hasil dari penelitiannya yaitu berupa media permainan kartu gambar dengan teknik make a match yang terdiri atas 23 set dengan beberapa subtema. Kartu yang telah dikembangkan dapat diaplikasikan dalam pembelajaran dengan menggunakan metode pembelajara make a match yaitu mencari pasangan dari gambar-gambar benda, buah, binatang.dan hal-hal lain dalam kartu tersebut.

Selain itu pengembangan kartu mengenai karier juga sudah dikembangkan oleh Zati Hanani tahun (2016) dengan sampel siswa SD kelas I, II, dan III di SD Negeri dalam jurnalnya yang berjudul "Pengembangan Kartu Karir sebagai Media Bimbingan Karir Siswa SD”. Penelitian ini menghasilkan dua macam kartu yaitu kaartu karir dan kartu karir pilihan. Peneliti juga membagi kartu karir ke dalam dua jenis yaitu pekerjaan orientasi orang dan pekerjaan orientasi bukan orang.

3. Desain

Pada tahap desain produk, peneliti menyusun tujuan yang ingin dicapai dan membuat materi yang akan dimasukan ke dalam media Kartu Tentang Pekerjaan (KTP). Tujuan dibuat sesuai dengan Standar Kemandirian Peserta Didik yaitu: Anak usia 7-10 tahun mampu mengenal ragam pekerjaan dan aktivitas di lingkungan sekitar. Tujuan tersebut didukung dengan media pembelajaran berupa Kartu Tentang Pekerjaan (KTP) yang meliputi Kartu Info Pekerjaan, Kartu Tebak Pekerjaan, Panduan dan Papan Permainan.

Kartu tentang Pekerjaan (KTP) adalah media bimbingan Karier yang dikembangkan berdasarkan teori Development Career Theory yang dikembangkan oleh Ginzberg. Teori Ginzberg ini mengemukakan bahwa perjalanan Karier seseorang berkembang sejak dini dan memiliki 3 tahapan yaitu: 1) Fantasi; 2) Tentatif; 3) Realistik. Media pembelajaran kartu ini sesuai dengan tahapan perkembangan fantasi menurut Ginzberg.Kartu Tentang Pekerjaan (KTP) ini memiliki dua model kartu yang berbeda, yaitu:

1) Kartu Info Pekerjaan

Kartu info ini berisi informasi mengenai pekerjaan-pekerjaan yang kurang terkenal dan kurang diketahui oleh anak-anak. Contohnya mengenai pramugari, fotografer, hakim, teknisi, dokter bedah, dan pekerjaan lainnya. Berikut adalah contoh desain Kartu Info Pekerjaan:

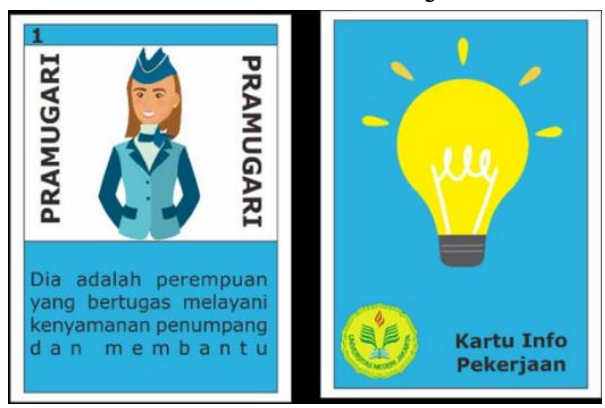

Gambar 2. Kartu Info Pekerjaan

2) Kartu Tebak Pekerjaan 
Kartu tebak pekerjaan adalah kartu yang dibuat untuk mengasah kemampuan nalar anak dan mengevaluasi pemahaman anak mengenai pekerjaan. Pekerjaan yang ditanyakan pada kartu tebak pertanyaan yaitu pekerjaan yang sering terlihat di masyarakat dan sudah terkenal. Contohnya yaitu guru, dokter, penyanyi, pedagang, dll. Berikut adalah contoh desain Kartu Tebak Pekerjaan:

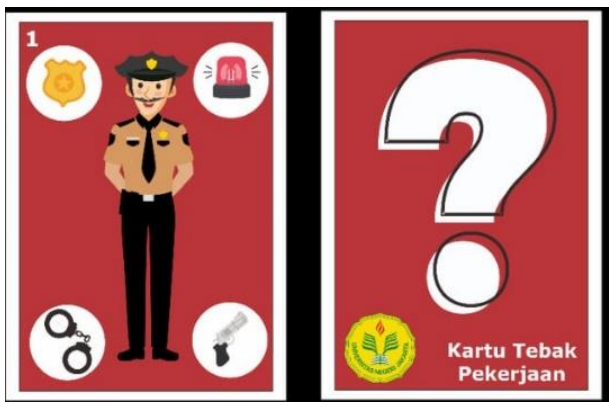

Gambar 3. Kartu Tebak Pekerjaan

3) Papan Permainan

Selain kartu peneliti juga telah membuat papan permainan berupa ular tangga, cara bermainnya juga mirip dengan permainan ular tangga. Berikut desain papan bermain:

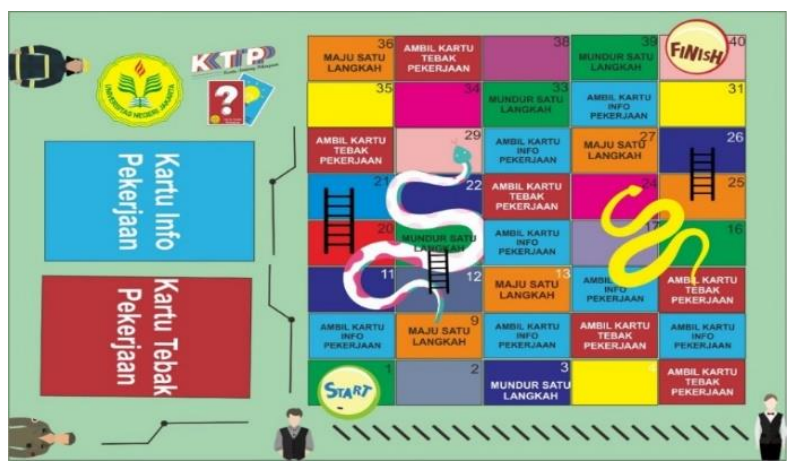

Gambar 4. Papan Permainan

4) Buku Panduan

Selain papan bermain, peneliti juga membuat panduan permainan untuk memudahkan fasilitator dalam melaksanakan layanan bimbingan. Metode yang digunakan adalah permainan ular melingkar, dengan konsep bermain sambil belajar untuk mengajarkan konsep pekerjaan, jenis-jenis pekerjaan, gerak fisik pada aktivitas ini dapat mengembalikan semangat kelas dan menarik perhatian anak. Berikut adalah tata cara permainan Kartu Tentang Pekerjaan:

1. Permaianan bisa diikuti minimal 2 pemain dan maksimal 4 pemain, atau sesuai dengan jumlah pion yang ada.

2. Letakan semua pion di kotak START lalu pemain menentukan urutan siapa yang bermain pertama, kedua dan seterusnya dengan hompimpa.

3. Masing - masing pemain melemparkan dadu dan menjalankan pion sesuai dengan angka yang dituju dadu.

4. Setiap pemain yang berhenti di kotak yang berisikan tulisan ambil kotak tebak prekerjaan wajib mengambil kartu yang berwarna merah dengan icon 
(?) kemudian menebak pekerjaan apa yang dimaksud. setelah menjawab, fasilitator kemudian menjelaskannya secara rinci dengan melihat buku panduan yang ada.

5. Setiap pemain yang berhenti di kotak yang berisikan tulisan Info kotak pekerjaan wajib mengambil kartu yang berwarna biru dengan icon lampu, kemudian membacakan profesi apa yang dimaksud dan pemain lain harus mendengarkan, fasilitator kemudian menjelaskannya secara rinci dengan melihat buku panduan yang ada.

6. Setiap pemain yang berhenti di kotak yang berisikan tulisan maju satu langkah, pemain harus maju satu kotak.

7. Setiap pemain yang berhenti di kotak yang berisikan tulisan mundur satu langkah, pemain harus mundur satu kotak.

8. Setiap pemain yang berhenti di kotak yang berisikan tulisan hukuman harus berhenti , jika ingin keluar dari kotak tersebut, pemain harus mengocok dadu hingga dadu menunjukan angka 6.

9. Setiap pemain yang berhenti di kotak yang berisi tulisan TANTANGAN harus menjalankan dan menyelesaikan tantangan yang diberikan oleh fasilitator.

10. Menjelang kotak FINISH ( nomor 39 ) jika dadu yang dilempar melebihi kotak FINISH maka pemain mundur lagi sesuai dengan hitungan yang ada di dadu.

11. Pemenang adalah pemain pertama yang sampai pertama tepat di kotak FINISH.

12. Setelah pemain berhasil menyelesaikan permainan, fasilitator wajib memberikan pertanyaan sesuai soal yang berada di buku panduan.

13. Kartu info dan tebak pekerjaan ada di tempat dan kotak terpisah.

Berikut desain buku panduan permainan yang telah dikembangkan oleh peneliti, Buku ini dilengkapi cara dan tahapan bermain serta link dan barcode untuk mengakses video cara bermain.:

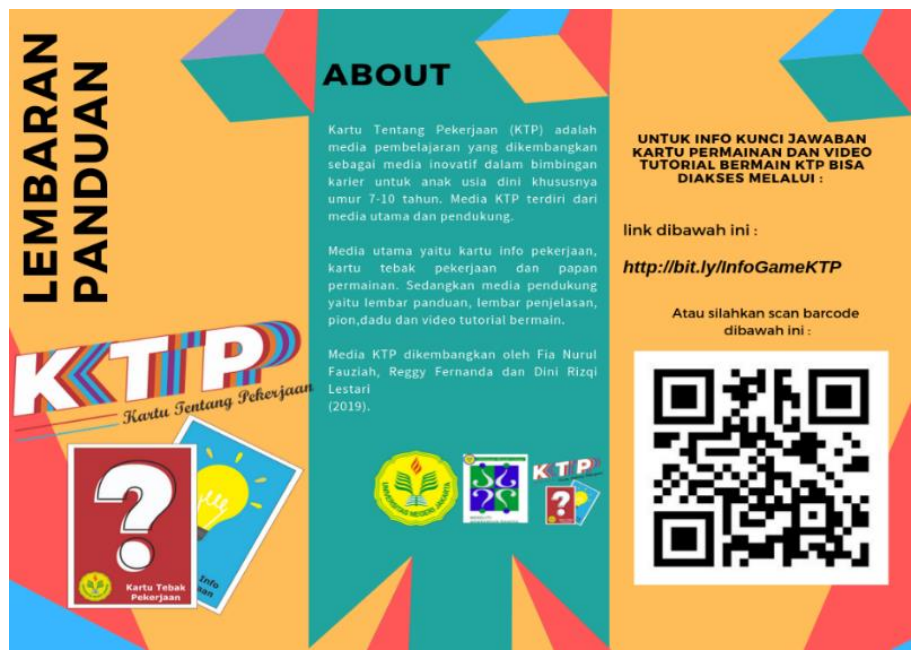




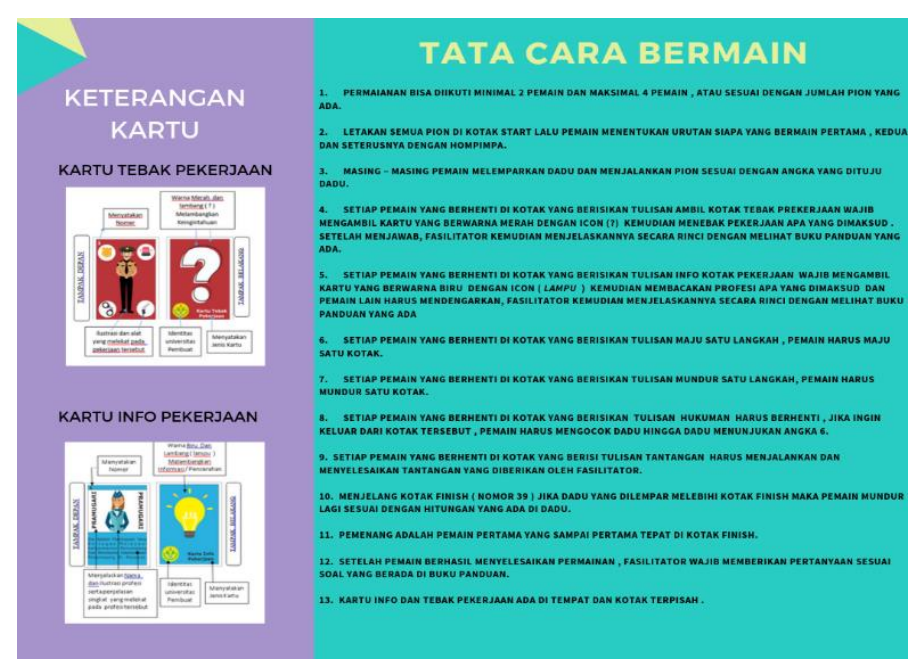

Gambar 5. Panduan Permainan

5) Kemasan Kartu

Peneliti membuat kemasan agar kartu-kartu yang telah dikembangkan tidak tercecer satu sama lain. Hal ini juga dibuat agar menambah masa pakai kartu agar tidak segera rusak atau hilang. Hal tersebut sesuai dengan syarat media yang baik dan benar.

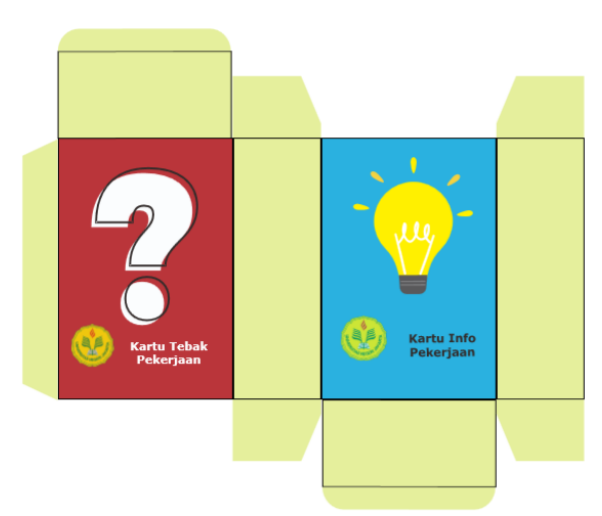

Gambar 6. Kemasan Kartu

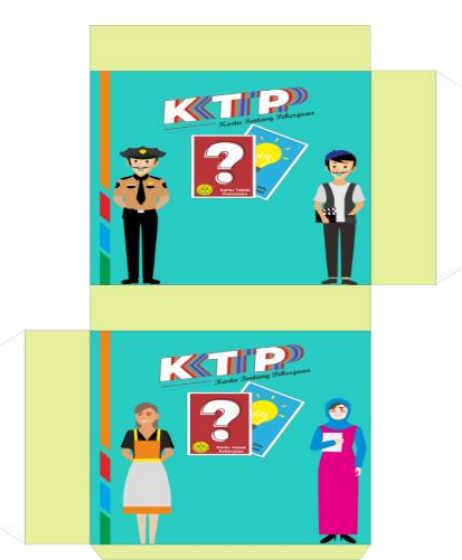

Gambar 7. Kemasan Panduan

Pengembangan Kartu Tentang Pekerjaan disesuaikan dengan aspek perkembangan anak dan syarat media pembelajaran bagi anak. Kartu Tentang Pekerjaan terbuat dari bahan kertas art karton yang aman digunakan oleh anak-anak, tidak mengandung zat yang berbahaya, desain yang dikembangkan menarik secara visual dan dapat mengembangkan motorik dan kreativitas anak, dapat digunakan oleh anak baik secara mandiri maupun berkelompok dalam jangka waktu yang cukup lama. Hal tersebut sesuai dengan syarat-syarat media pembelajaran yang baik bagi anak, yaitu aman dan tidak membahayakan untuk anak anak-anak, indah, rapi dan menarik, tidak membosankan bagi anak, dapat digunakan secara individual atau berkelompok, memicu kreativitas anak dan dapat dimanfaatkan dalam waktu yang cukup lama (Kustiawan, 2016).

4. Validasi

Validasi Desain dalam penelitian media ini meliputi tahap penilaian yang dilakukan oleh dua ahli yaitu: 1 orang ahli materi dan 1 orang ahli media. Ahli materi 
dan media dari Dosen Program Studi Bimbingan dan Konseling Universitas Negeri Jakarta. Berdasarkan hasil validasi materi untuk menilai kelayakan materi diperoleh hasil sebagai berikut:

Tabel 1. Hasil validasi ahli materi

\begin{tabular}{llllll}
\hline No & Aspek & $\sum$ Butir & $\sum$ Skor & Persentase & Kriteria \\
\hline 1. & Penyajian & 3 & 12 & & Sangat Baik \\
2. & Pemilihan Tema & 3 & 12 & $80 \%$ & Sangat Baik \\
3. & Isi Materi & 4 & 16 & & Sangat Baik
\end{tabular}

Sedangkan untuk hasil validasi media untuk menilai kelayakan media diperoleh hasil sebagai berikut:

Tabel 2. Hasil validasi ahli media

\begin{tabular}{llllll}
\hline No & Aspek & $\sum$ Butir & $\sum$ Skor & Persentase & Kriteria \\
\hline 1. & Fisik & 5 & 40 & & Sangat Baik \\
2. & Desain & 6 & 24 & $86,6 \%$ & Sangat Baik \\
3. & Penggunaan & 2 & 10 & & Sangat Baik \\
\hline
\end{tabular}

Berdasarkan data hail evaluasi formatif dari validator yang terdiri dari ahli materi dengan aspek penyajian, pemilihan tema, serta isi materi mencapai $80 \%$ yang dapat diartikan sangat baik. Sedangkan penilaian ahli media dengan aspek fisik, desain, serta penggunaan mencapai angka $86,6 \%$ yang dapat diartikan sangat baik. Hasil penilaian dari ahli materi dan media berada pada kategori sangat baik, artinya media Kartu Tentang Pekerjaan sangat layak dijadikan media pendukung layanan karir baik di sekolah maupun di masyarakat, khususnya untuk anak 7-10 tahun. Media yang dikembangkan peneliti diharapkan dapat mempermudah anak-anak dalam memahami berbagai pekerjaan yang ada dalam kehidupan sehari-hari.

Setelah melakukan validasi media kepada ahli materi dan ahli media, ahli menyarankan peneliti untuk melakukan uji coba kepada anak untuk menguji keterbacaan Kartu Tebak Pekerjaan. Uji coba dilakukan pada tanggal 27 September 2019, Pukul 13.30. Uji coba dilakukan dengan metode one to one yaitu mendatangi anak secara langsung atau secara individu untuk mendapatkan sebuah informasi mengenai sesuatu hal. Ada 3 anak yang diikutsertakan dalam uji coba ini dalam waktu yang berbeda. Berdasarkan analisis yang peneliti lakukan terhadap 3 anak yang diikutsertakan dalam uji coba, peneliti dapat mengambil kesimpulan bahwa masih ada media Kartu Tebak Pekerjaan yang masih sulit untuk dipahami oleh anak usia 7-10 tahun. Kartu Tebak Pekerjaan yang paling sulit ditebak yaitu sales, aktor, pedagang dan kasir. Hal ini tentunya menjadi suatu perhatian penting bagi peneliti dan dijadikan pertimbangan yang cukup besar untuk mengganti beberapa ciri-ciri pekerjaan dalam Kartu Tebak Pekerjaan.

5. Revisi

Perubahan pada media yang dikembangkan setelah revisi pada ahli materi yaitu: 1) Mengganti beberapa ciri dalam Kartu Tebak Pekerjaan menjadi lebih relevan dan mudah dimengerti; 2) Mengganti beberapa pengertian dalam Kartu Info Pekerjaan. 
Sedangkan perubahan media setelah mendapatkan revisi dan saran dari ahli media yaitu: 1) Penggantian ukuran kemasan, menyesuaikan dengan banyaknya kartu agar lebih efektif; dan 2) Mengganti model papan bermain ular tangga yang terlalu sering digunakan menjadi papan permainan seperti berikut:

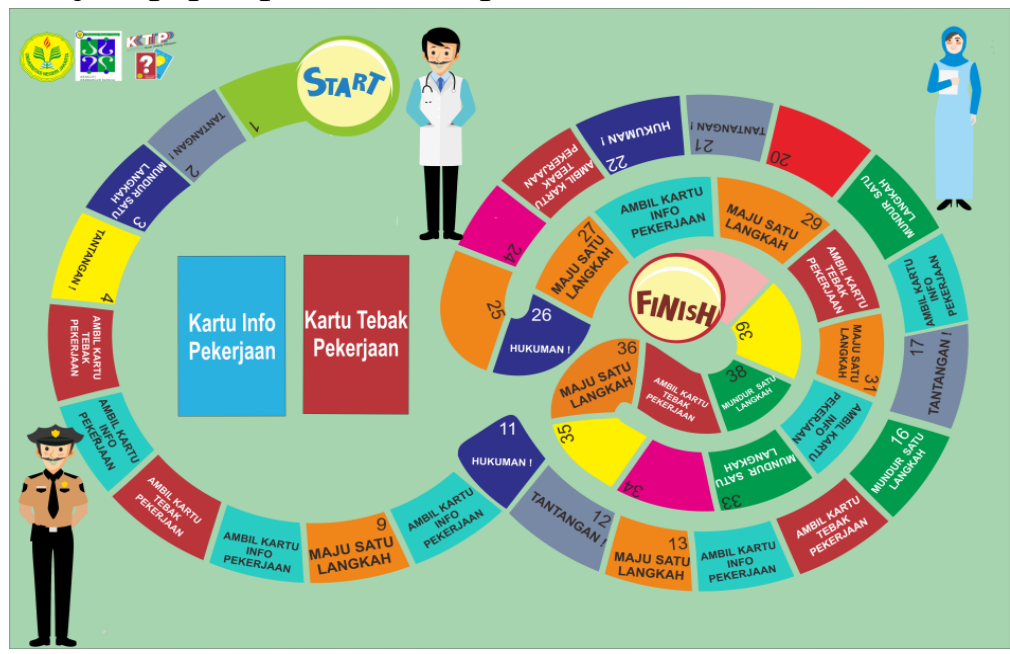

Gambar 8. Revisi Papan Permainan

Beberapa revisi pada desain Kartu Tebak Pekerjaan yaitu: 1) menghilangkan gambar pistol atau senjata api pada Kartu Tebak Pekerjaan Polisi; 2) menghilangkan senjata api pada Kartu Tebak Pekerjaan TNI; 3) mengganti baju pedagang yang menyerupai pelayan; 4) mengganti gambar ayam pada ciri-ciri Kartu Tebak Pekerjaan Petani dengan gambar sawah. Berikut perubahan desain kartu setelah direvisi:
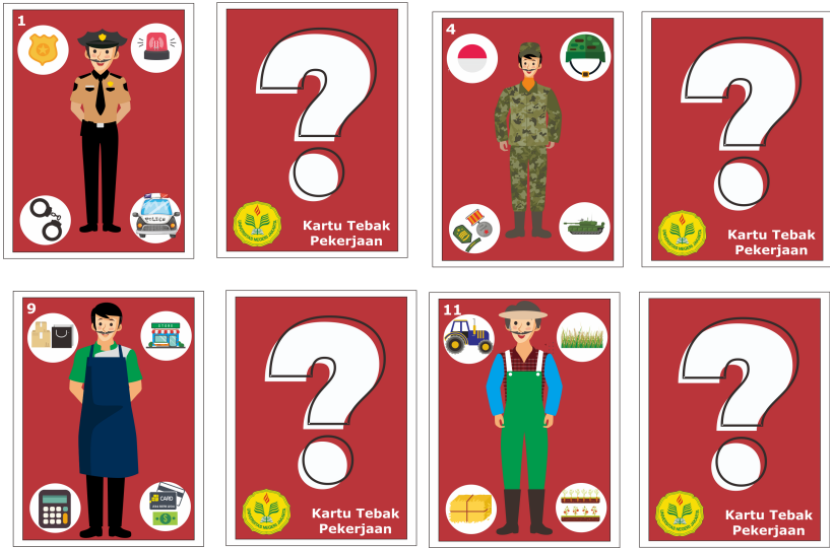

Gambar 9. Revisi Kartu Tebak Pekerjaan

Penelitian ini memiliki beberapa keterbatasan yang masih harus diperbaiki agar dapat dimanfaatkan secara maksumal dan sesuai dengan kebutuhan anak. Beberapa keterbatasan tersebut adalah: 1) Pengembangan media hanya sampai pada tahap revisi setelah media divalidasi oleh ahli materi dan media dan 2) Uji coba tidak dilakukan dalam penelitian ini karena adanya keterbatasan waktu penelitian yang dilakukan, sehingga belum dapat mengujicobakan media secara langsung kepada anak usia 7-10 tahun di RPTRA Beringin Indah.

\section{PENUTUP}

Berdasarkan hasil penelitian mengenai pengembangan media Kartu Tentang Pekerjaan mengenai jenis-jenis pekerjaan dapat ditarik kesimpulan bahwa media Kartu 
Tentang Pekerjaan untuk anak usia 7-10 tahun di RPTRA Beringin Indah sangat layak untuk digunakan sebagai media bimbingan karir dengan hasil presentase validasi media $86,6 \%$ dan hasil validasi materi $80 \%$ yang termasuk dalam ketegori sangat baik.

Kompetensi yang ingin dicapai dalam pengembangan media KTP adalah Anak usia 7-10 tahun mampu mengenal ragam pekerjaan dan aktivitas di lingkungan sekitar, sesuai dengan Standar Kompetensi Kemandirian Peserta Didik (SKKPD) pada jenjang Sekolah Dasar. Saran ahli terhadap media dalam penelitian ini yaitu mengganti ukuran kemasan, menyesuaikan dengan banyaknya kartu agar lebih efektif, mengganti model Papan Bermain, merevisi desain Kartu Info Pekerjaan dan Kartu Tebak Pekerjaan, mengganti beberapa ciri dalam Kartu Tebak Pekerjaan menjadi lebih relevan dan mudah dimengerti dan mengganti beberapa pengertian dalam Kartu Info Pekerjaan

Berdasarkan hasil penelirian dan kesimpulan diatas maka terdapat saran-saran sebagai berikut : 1) Bagi peneliti selanjutnya, penelitian ini bisa dilakukan hingga tahap uji coba produk dan revisi lanjutan agar dapat dimanfaatkan oleh masyarakat pengguna Kartu Tentang Pekerjaan atau Guru BK di Sekolah Dasar. Penelitian ini juga diharapkan dapat dikembangkan lagi sesuai dengan asas kekinian yaitu menggunakan teknologi terkini; 2) Bagi praktisi, diharapkan dapat menyampaikan materi mengenai macam-macam pekerjaan dalam layanan karier dengan baik.

\section{DAFTAR PUSTAKA}

Afandi, M., 2011. Tipe kepribadian dan model lingkungan dalam prespektif bimbingan karir john holland. Jurnal Sosial dan Budaya, 8(1), pp. 86-97.

Batubara, J., 2013. Perkembangan dan pemilihan karier menurut ginzberg. Jurnal Konseling dan Pendidikan, I(1).

Ginzberg, E., 1971. Analysis, Information and Counseling and Guidance. Dalam: Readings in Guidance. New York: MSS Educational Publishing Company, pp. 7477.

Gysbers, N., 2005. Comprehensive School Guidance Programs in The United States : A Carier Profile. s.l.:International Journal for Education Vacational Guidance.

Hanani, Z., 2016. Pengembangan Kartu Karir Sebagai Media Bimbingan Karier Siswa SD. E-Journal Bimbingan dan Konseling, 9(5), pp. 313-337.

Herlina, N. \& Nadiroh, 2017. Peran strategis ruang publik terpadu ramah anak dalam rangka pemenuhan hak anak terhadap lingkungan. Jurnal pendidikan Usia Dini.

Kemendikbud, 2011. Peraturan Menteri Pendidikan dan Kebudayaan Republik Indonesia nomor 111 tentang Bimbingan dan Konseling pada Pendidikan Dasar dan Pendidikan Menengah. Jakarta: s.n.

Kemendikbud, 2016. Panduan Operasional Penyelenggaraan Bimbingan dan Konseling Sekolah Menengah Pertama. Jakarta: s.n.

Kustiawan, U., 2016. Pengembangan Media Pembelajaran Anak Usia Dini. Malang: Gunung Samudra.

Lestari, I., 2017. Meningkatkan kematangan karir remaja melalui bimbingan karir berbasis life skills. Jurnal Konseling Gusjijang, 3(1), pp. 17-28.

Sugiono, 2009. Metode Penelitian Pendidikan Pendekatan Kuantitatif, Kualitatif dan $R \& D$. Bandung: Alfabeta.

Wardati, A. \& Wangid, M. N., 2015. Pengembangan Media Kartu Gambar dengan Teknik Make a Match untuk Kelas 1 SD. Jurnal Primaedukasia, 3(2), pp. 120-132. 